\title{
Assessment of tooth preparation for prosthetic crowns - based on selected literature
}

\section{Ocena preparacji zębów pod korony protetyczne - na podstawie wybranego piśmiennictwa}

\author{
Aneta Januszewska, Beata Dejak \\ Zakład Protetyki Stomatologicznej, Uniwersytet Medyczny w Lodzi \\ Department of Prosthodontics, Medical University in Lodz \\ Head: prof. dr hab. n. med. Beata Dejak
}

\section{KEY WORDS:}

crown preparation, convergence angle, finish lines

\section{Summary}

The paper presents selected methods of assessment of tooth preparation based on the literature, among others, computer software cooperating with scanners, e.g. Preppr, DentSim, PREPassistant, E4D Compare, PrepCheck and Simodont Dental Trainer. During tooth preparation for prosthetic restorations, it is necessary to create sufficient space, which will allow the technician to construct an aesthetic and durable restoration. Hard tissues should be prepared very sparingly, while at the same time providing retention and stabilization as well as marginal integration for future restoration. The anatomy of the occlusal surface should be preserved, and the axial walls reduced to the proper thickness to obtain an optimal degree of convergence angle, which equals $6^{\circ}$. The most common errors in tooth preparation for crowns are inadequate reduction of the occlusal surface, the lack of functional cusp bevel and incorrect finish line width. The occlusal surface is excessively reduced on average by $15 \%$, whereas the width of the finish line on the vestibular surface is about $28 \%$ too small. The results of the convergence angle measurement exceed three times the recommended values in the literature, which can adversely affect the retention of restoration.
HASŁA INDEKSOWE:

preparacja pod koronę, kąt zbieżności, stopień przydziąsłowy

\section{Streszczenie}

$W$ pracy przedstawiono na podstawie piśmiennictwa wybrane metody oceny preparacji zębów, między innymi programy komputerowe wspótpracujace ze skanerami np. Preppr, DentSim, PREPassistant, E4D Compare, PrepCheck oraz Simodont Dental Trainer. Podczas preparacji zębów pod uzupetnienia protetyczne należy stworzyć przestrzeń dla przyszłego uzupetnienia, aby technik mógł wykonać prace o prawidłowej wytrzymatości i estetyce. Tkanki twarde zębów należy szlifować bardzo oszczędnie, jednocześnie zapewniajac retencje $i$ stabilizacje oraz integracje brzeżna przyszłym uzupetnieniom. Należy zachować anatomie powierzchni żujacej, a ściany osiowe zredukować na odpowiednia grubość, uzyskujac optymalny stopień zbieżności, który wynosi $6^{\circ}$. Najczęstsze błędy w opracowaniu zębów pod korony to nieodpowiednia redukcja powierzchni zgryzowej, brak ścięcia stoku guzka funkcjonalnego oraz nieprawidtowa szerokość stopienia przydziąsłowego. Powierzchnia zgryzowa jest redukowana średnio o $15 \%$ za dużo, natomiast szerokość stopnia na powierzchni przedsionkowej jest o ok. $28 \%$ za mała. Wyniki pomiarów kąta zbieżności przekraczaja ponad trzykrotnie zalecana wartość podana w literaturze, co może negatywnie wptywać na retencję uzupetnień. 


\section{Introduction}

During tooth preparation procedure for prosthetic restorations it is recommended to follow four main principles: saving tooth tissues, creating proper retention and stability of restorations, obtaining adequate mechanical strength and integrating restorations with dental tissues. ${ }^{1}$ The crown is not supposed to rebuild lost tissues only, but also to protect tooth from further damage.

Tooth preparation for a prosthetic crown can be divided into several stages: incisal or occlusal reduction, preparation of the axial walls with initial preparation of the finish lines, final preparation of the finish lines and smoothing of the prepared surfaces. For example, to prepare posterior teeth for a metalceramic crown, functional cusps should be reduced by $2 \mathrm{~mm}$, fissure and non-functional cusps by $1.5 \mathrm{~mm}$. The convergence angle of the axial walls should be $6^{\circ}$. On the buccal surface heavy chamfer or radial shoulder finish line of $1.2 \mathrm{~mm}$ in width should be prepared. However, on the lingual, mesial and distal surfaces a light chamfer finish line is recommended of $0.7 \mathrm{~mm}$ in depth. ${ }^{2}$

During anterior teeth preparation for the full ceramic crown, vestibular surface should be prepared in two planes, joining in place of the largest tooth protuberance. The incisal edge should be reduced by $2.0 \mathrm{~mm}$. The palatal surface is reduced by $1.0-1.5 \mathrm{~mm}$. The angle between a gingival part of the palatal surface and a labial surface is $6-15^{\circ}$. Rounded shoulder finish line should be $0.8-1.0 \mathrm{~mm}$ wide. ${ }^{2}$

It is significant to maintain the anatomy of the occlusal surface. This saves the hard tissues of the tooth, improves the stabilization of restorations and enables correct modeling of the occlusal surface of the crown, which is important for static and dynamic occlusion. ${ }^{3}$ Insufficient preparation of the occlusal surface may result in lack of space for

\section{Wprowadzenie}

Podczas procedury szlifowania zębów pod uzupełnienia stałe, zalecane jest kierowanie się czterema głównymi zasadami: oszczędność tkanek zęba, stworzenie prawidłowej retencji i stabilności uzupełnień, uzyskanie odpowiedniej wytrzymałości mechanicznej oraz zintegrowanie protez stałych z tkankami zęba. ${ }^{1}$ Korona ma za zadanie nie tylko odbudować utracone tkanki, ale także ochronić ząb przed dalszym uszkodzeniem.

Opracowanie zęba pod koronę protetyczną można podzielić na kilka etapów: redukcja brzegu siecznego lub powierzchni żującej, szlifowanie ścian osiowych ze wstępnym opracowaniem stopnia, ostateczne kształtowanie schodka i wygładzenie oszlifowanych ścian. Przykładowo w celu opracowania zębów bocznych pod koronę metalowo-ceramiczną należy zredukować guzki funkcjonalne na głębokość $2 \mathrm{~mm}$, a bruzdę i guzki niefunkcjonalne na 1,5 mm. Kąt zbieżności ścian osiowych powinien wynosić $6^{\circ}$. Od strony policzkowej należy wytworzyć stopień typu heavy chamfer lub radial shoulder o szerokości 1,2 mm, natomiast od strony powierzchni językowej i stycznych stopień light chamfer o głębokości 0,7 mm. ${ }^{2}$

Podczas opracowania pod koronę pełnoceramiczną zębów przednich powierzchnię przedsionkową należy preparować w dwóch płaszczyznach, łączących się w miejscu największej wypukłości zęba. Brzeg sieczny należy zredukować o 2,0 mm. Powierzchnia podniebienna jest szlifowana na głębokość 1,0-1,5 mm. Część przydziąsłowa powierzchni podniebiennej powinna być pod kątem $6-15^{\circ}$ do powierzchni wargowej. Należy opracować stopień rounded shoulder o szerokości $0,8-1,0 \mathrm{~mm} .^{2}$

Istotne znaczenie ma dbałość o zachowanie anatomii powierzchni żującej. Pozwala to zaoszczędzić tkanki twarde zęba, polepsza stabilizację uzupełnienia oraz umożliwia prawidłowe wymodelowanie powierzchni zgryzowej 
future prosthetic crown. Too thin restoration on the occlusal surface may be exposed to perforation during mechanical preparation or use. Too little material thickness affects not only the strength but also the aesthetics of the future restoration. Preparation of functional cusp bevel is necessary to obtain space for the crown during dynamic occlusion. ${ }^{1}$ The reduction of axial walls is also important. Insufficient preparation of axial walls can lead to an excessively modeled crown. The correct preparation of the finish lines determines the smooth transition of the crown into the tooth tissue, which affects the periodontium. The crown retention is affected by the ratio of two opposing axial surfaces of the tooth (the optimal degree of convergence angle is $6^{\circ}$ ), the size of the prepared surface, the height of the tooth crown and the type of cement.

\section{Methods of assessment of tooth preparation for prosthetic restorations}

Many researchers conducted study aimed at assessing the quality of tooth preparation for prosthetic crowns. There are several methods of measuring the extent of preparation. The program that can be used to evaluate the preparation is Preppr. It uses files in the STL format, divides it into sections and automatically determines points for measuring tooth preparation. Following the preparation, the teeth are scanned with a 3-D scanner. Then, the STL file is imported into Preppr providing the 3-D image of the prepared tooth in any plane. Other available software are: DentSim (Image Navigation Ltd., USA), PREPassistant (KaVo Dental GmbH, Germany), PrepCheck (Sirona Dental Systems, USA) E4D Compare (E4D TechnoloGies, USA), and Simodont Dental Trainer (Moog Industrial Group, The Netherlands). ${ }^{4}$

Another method of measurement is to make an impression of the study cast using korony, co ma istotne znaczenie dla okluzji statycznej i dynamicznej. ${ }^{3}$ Zbyt małe oszlifowanie powierzchni okluzyjnej może być przyczyną braku miejsca dla przyszłej korony protetycznej, za cienkie uzupełnienie na powierzchni żującej może być narażone na sperforowanie $\mathrm{w}$ trakcie obróbki mechanicznej czy też w trakcie użytkowania. Zbyt mała grubość materiału wpływa nie tylko na wytrzymałość, ale również na estetykę przyszłego uzupełnienia. Skośne oszlifowanie stoków guzków funkcjonalnych jest niezbędne, aby uzyskać miejsce dla korony podczas okluzji dynamicznej. ${ }^{1}$ Ważna jest także redukcja ścian osiowych zęba, która wykonana niedostatecznie, może prowadzić do przekonturowania korony. Prawidłowe opracowanie stopnia decyduje o gładkim przejściu korony w tkanki zęba, co ma wpływ na przyzębie. Na retencję korony wpływa stosunek dwóch przeciwstawnych powierzchni osiowych zęba (optymalny stopień zbieżności ścian wynosi $6^{\circ}$ ), wielkość powierzchni opracowania, wysokość korony zęba oraz rodzaj zastosowanego cementu.

\section{Metody oceny preparacji zębów pod uzupelnienia protetyczne}

Wielu autorów prowadziło badania, których celem była ocena jakości opracowania zębów pod korony protetyczne. Istnieje kilka metod pomiaru zakresu preparacji. Programem, który można użyć do oceny preparacji jest Preppr. Wykorzystuje pliki w formacie STL, dzieli na przekroje i automatycznie wyznacza punkty w celu wykonania pomiaru opracowania zęba. Zęby po opracowaniu są skanowane za pomocą skanera 3D. Następnie plik STL zostaje zaimportowany do programu Preppr, przez co uzyskiwany jest obraz 3D zęba po opracowaniu w dowolnej płaszczyźnie. Inne dostępne oprogramowania to: DentSim (Image Navigation Ltd., USA), PREPassistant (KaVo Dental GmbH, Niemcy), E4D Compare (E4D Technologies, USA), PrepCheck (Sirona Dental Systems, 
putty polyvinylsiloxane material and then, after removing the impression from the cast, applying light body material and making an impression of the working cast. The impression procedure should be performed twice, because one impression is sectioned bucco-lingually (BL) and the other mesio-distally (MD). Projected images are obtained using a projector and transparent paper. Then two lines are drawn along the opposing walls and the angle of convergence is measured with a protractor. However, incisal/occlusal reduction (functional cusps, non-functional cusps and fissure) and axial reduction (buccal, lingual, mesial and distal surfaces) can be measured directly on the impression using a digital caliper. On the working cast, it is also possible to investigate the continuity and location of the finish line and the smoothness of the prepared teeth. ${ }^{5}$ According to other studies, the obtained part of the index can be placed on a microscope slide and further images are recorded by an optical microscope (Olympus) with a resolution of $\pm 0.02 \mathrm{~mm}$ connected to a computer. Calibrated image analysis software (Klonk Image Measurement) can be used for measurement. ${ }^{6}$

Reports also describee how to measure the range of the preparation based on an intact tooth on the other side of the arch. Reduction in BL and MDdimension(BLR and MDR) is the difference between the largest distance between the buccal and lingual surfaces, as well as the mesial and distal surface of a healthy tooth contralaterally (BLA and MDA) and the corresponding BL and MD dimension of the tooth after preparation (BLD and MDD). Measurements can be made with a digital caliper held perpendicularly to the occlusal plane and along the long axis of the tooth. Average reduction values in the BL and MD plane are statistically compared with the hypothetically calculated ideal reduction (HCIR), which according to the authors is 2.15 $\mathrm{mm}( \pm 0.25)$ in the BL plane and $2.2 \mathrm{~mm}( \pm 0.2)$ in the MD plane. ${ }^{7}$
USA) oraz Simodont Dental Trainer (Moog Industrial Group, Holandia). ${ }^{4}$

Innym sposobem pomiaru jest wykonanie za pomocą masy poliwinylosiloksanowej typu putty wycisku modelu diagnostycznego, a następnie po zdjęciu wycisku z modelu, nałożenie masy light body i wykonanie wycisku modelu roboczego. Procedurę wyciskową należy wykonać dwukrotnie, ponieważ jeden wycisk jest przekrojony w płaszczyźnie policzkowo-językowej (BL), a drugi w płaszczyźnie mezjalno-dystalnej (MD). Za pomocą rzutnika i przezroczystego papieru uzyskuje się rzuty, na których rysuje się dwie przeciwstawne linie wzdłuż ścian i mierzy kątomierzem kąt zbieżności. Natomiast bezpośrednio na wycisku przy użyciu suwmiarki cyfrowej można zmierzyć redukcję brzegu siecznego, powierzchni okluzyjnej (guzków pracujących, guzków niepracujących i bruzdy) oraz redukcję osiową (powierzchnia policzkowa, językowa, mezjalna i dystalna). Na modelu roboczym można również zbadać ciągłość i umiejscowienie stopnia przydziąsłowego oraz gładkość powierzchni opracowanych zębów. ${ }^{5}$ Według innych badań uzyskaną w ten sposób przedzieloną część indeksu można umieścić na szkiełku mikroskopowym i zarejestrować obraz przez mikroskop optyczny (Olympus) o rozdzielczości $\pm 0,02 \mathrm{~mm}$ podłączony do komputera. Do pomiaru można zastosować skalibrowane oprogramowanie do analizy obrazu (Klonk Image Measurement) ${ }^{6}$.

Opisany jest także sposób mierzenia zakresu preparacji na podstawie nieuszkodzonego zęba po drugiej stronie łuku. ${ }^{7}$ Redukcja w wymiarze BL (BLR) i MD (MDR) jest różnicą między największą odległością między powierzchnią policzkową a językową oraz powierzchnią mezjalną a dystalną zdrowego zęba po przeciwnej stronie łuku (BLA i MDA) oraz odpowiednim wymiarem BL i MD zęba po opracowaniu (BLD i MDD). Pomiary można wykonać za pomocą suwmiarki cyfrowej trzymanej prostopadle do płaszczyzny zgryzu 
In order to measure the convergence angle in two planes and the axial wall taper, prepared teeth should be removed from the model and mounted in a block of hard wax in a fixed position. Then, on a white background, photgraphs of the teeth are taken in the mesiodistal and buccolinual plane with the digital camera on a tripod perpendicular to the long axis of the tooth. Pictures of each tooth are transferred to AutoCAD 2007 software (Sony Corporation, Tokyo, Japan) for measurements. ${ }^{8}$ The convergence angle can also be examined thanks to coordinate metrology. ${ }^{9}$ A coordinate measuring machine has a probe and three measuring systems. It allows one to measure an object with a very complex structure. The measurements are accurate and objective.

In studies conducted by Tiu et al. ${ }^{10}$ teeth prepared by doctors for all-ceramic crowns were evaluated. The angle of convergence ranged from $18^{\circ}$ to $52^{\circ}$. Patel et al. ${ }^{11}$ compared the angle of convergence of posterior teeth prepared for gold crowns by the fourth and fifth year undergraduate dental students, clinical teaching staff and general dental practitioners. The convergence angles for the fourth-year students averaged $24^{\circ}$ and $27^{\circ}$ in the buccolingual (BL) and mesiodistal (MD) planes respectively. These results averaged $15^{\circ}$ (BL) and $16^{\circ}(\mathrm{MD})$ for the fifth-year students. On the other hand, for teaching staff in both planes it was on average $17^{\circ}$ and for general dental practitioners $15^{\circ}$. The results show that the least experienced group of students obtained the largest range of the convergence angle $\left(10^{\circ}-82^{\circ}\right)$. The results of Ghafoor et al. ${ }^{8}$ show that the convergence angle of the axial walls of teeth prepared by doctors was on average $23 \cdot 7^{\circ} \pm 8.9^{\circ}$. According to Andreescu et al., ${ }^{12}$ the average convergence angle was $26.54^{\circ}$. According to the research carried out by Rafeek et al., ${ }^{13}$ the angle of convergence of teeth prepared by students i wzdłuż długiej osi zęba. Średnie wartości redukcji w płaszczyźnie BL i MD są porównywane statystycznie z hipotetycznie obliczoną idealną redukcją (HCIR), która według autorów wynosi w płaszczyźnie BL 2,15 mm $( \pm 0,25)$, a w płaszczyźnie MD 2,2 mm $( \pm 0,2){ }^{7}$

W celu zmierzeniastopnia zbieżnościw dwóch płaszczyznach i nachylenia każdej ściany należy usunąć z modelu kikuty opracowanych zębów i zamontować w kwadratowym bloku z twardego wosku w stałej pozycji. Następnie na białym tle wykonuje się zdjęcia zębów w płaszczyźnie mezialno-dystalnej oraz policzkowo-językowej aparatem cyfrowym na statywie prostopadle do długiej osi zęba. Zdjęcia każdego kikuta przenosi się do oprogramowania AutoCAD 2007 (Sony Corporation, Tokio, Japonia) w celu dokonania pomiarów. ${ }^{8}$ Kąt zbieżności można także zbadać dzięki metrologii współrzędnościowej. ${ }^{9}$ Współrzędnościowa maszyna pomiarowa posiada sondę oraz trzy systemy pomiarowe. Pozwala zmierzyć przedmiot o bardzo złożonej budowie. Dokonane pomiary są dokładne i obiektywne.

W badaniach przeprowadzonych przez Tiu i wsp. ${ }^{10}$ oceniano opracowanie zębów pod koronę pełnoceramiczną przez lekarzy. Zakres kąta zbieżności wynosił od $18^{\circ}$ do $52^{\circ}$. Patel i wsp. ${ }^{11}$ porównali kąt zbieżności zębów bocznych opracowanych pod złote korony przez studentów czwartego i piątego roku stomatologii, lekarzy dentystów oraz pracowników dydaktycznych doświadczonych w zakresie protetyki. Kąty zbieżności dla studentów czwartego roku wynosiły średnio $24^{\circ}$ i $27^{\circ}$ odpowiednio w płaszczyznach policzkowo-językowej (BL) i mezjalno-dystalnej (MD). Dla studentów piątego roku wyniki te wynosiły $15^{\circ}(\mathrm{BL})$ i $16^{\circ}$ (MD). Natomiast dla pracowników dydaktycznych w obu płaszczyznach kąt ten wynosił średnio $17^{\circ}$, zaś dla lekarzy dentystów $15^{\circ}$. Wyniki wskazują, że największy zakres kąta zbieżności uzyskała najmniej doświadczona grupa studentów $\left(10^{\circ}-82^{\circ}\right)$, a w żadnej 
was on average $20.3^{\circ} \pm 11.3^{\circ}$ in the mesiodistal plane, and $18.3^{\circ} \pm 8.5^{\circ}$ in the buccolingual plane. According to Al-Omari et al. ${ }^{14}$ the mean values in the buccolingual and mesiodistal plane were $22.4^{\circ}$ and $25.3^{\circ}$, respectively. Studies by El-Mubarak et al. ${ }^{5}$ show even higher results of the convergence angle of teeth prepared by students. The average value was $39.98^{\circ}$. The convergence angles were $44.1^{\circ}$ on the buccolingual plane and $35.8^{\circ}$ on the mesiodistal plane. No tooth had an average convergence angle within acceptable limits $\left(10^{\circ}-20^{\circ}\right) \cdot 8.5 \%$ of the prepared teeth had an acceptable convergence angle in the MD plane and only $0.85 \%$ in the BL plane.

The incisal/occlusal reduction ranged from 1.8 to $2.2 \mathrm{~mm}$ and averaged $2 \mathrm{~mm} .{ }^{14}$ Based on the research of El-Mubarak et al. ${ }^{5}$ the incisal reduction was on average $2.3 \mathrm{~mm}$, which is statistically significant when compared to the ideal value. The occlusal reduction of the posterior teeth was on average $2.29 \mathrm{~mm}$ for functional cusps, $1.76 \mathrm{~mm}$ for non-functional cusps and $1.6 \mathrm{~mm}$ for the central fissure. ${ }^{5}$ Incisal/occlusal reduction was sufficient in $62.77 \%$ of cases. ${ }^{12}$ However, according to other studies, the occlusal reduction was appropriate in only $33.93 \%$ of cases. $^{7}$

The axial reduction was $1.45 \mathrm{~mm}$ on the vestibular surface, $1.00 \mathrm{~mm}$ on the lingual surface, $1.42 \mathrm{~mm}$ on the mesial and $1.37 \mathrm{~mm}$ on the distal surface. ${ }^{5}$ Preparation of axial walls was sufficient in $54.01 \%$ of cases. $12.41 \%$ of prepared teeth had undercuts and $21.17 \%$ had sharp angles. ${ }^{12}$

According to Al-Omari et al. ${ }^{14}$ shoulder finish line depth on the buccal surface was on average $0.86 \mathrm{~mm}$, while the average chamfer finish line on the lingual surface was 0.74 $\mathrm{mm}$, on the mesial surface $0.7 \mathrm{~mm}$ and on the distal surface $0.66 \mathrm{~mm}$. The buccal shoulder finish line for the anterior mandibular teeth was significantly smaller than for the other teeth and was only $0.45 \mathrm{~mm}$ on average. ${ }^{14}$ grupie stopień zgodności z idealną zbieżnością $\left(4^{\circ}-14^{\circ}\right)$ nie był większy niż $50 \%$. Ghafoor i wsp. w swoich badaniach wykazali, że kąt zbieżności ścian osiowych zębów opracowanych przez lekarzy wynosił średnio $23,7^{\circ} \pm 8,9^{\circ} .{ }^{8}$ Według Andreescu i wsp. ${ }^{12}$ średnia wartość kąta zbieżności wynosiła $26,54^{\circ}$. Zgodnie z badaniami przeprowadzonymi przez Rafeek i wsp. ${ }^{13}$ kąt zbieżności zębów opracowanych przez studentów wynosił średnio $20,3^{\circ} \pm 11,3^{\circ}$ w płaszczyźnie mezjalno-dystalnej i $18,3^{\circ} \pm 8,5^{\circ}$ w płaszczyźnie policzkowo-językowej. Według Al-Omari i wsp. ${ }^{14}$ średnia wartość kąta nachylenia ścian w płaszczyźnie policzkowo-językowej oraz mezjalno-dystalnej wynosiła odpowiednio $22,4^{\circ}$ oraz $25,3^{\circ}$. Natomiast badania El-Mubarak i wsp. ${ }^{5}$ wskazują na jeszcze wyższe wyniki kąta zbieżności zębów opracowanych przez studentów. Średnia wartość wynosiła $39,98^{\circ} ; 44,1^{\circ} \mathrm{W}$ płaszczyźnie policzkowo-językowej i 35,8 $\mathrm{w}$ płaszczyźnie mezjalno-dystalnej. Żaden ząb nie miał średniej wartości kąta zbieżności w akceptowalnych granicach $\left(10^{\circ}-20^{\circ}\right)$, zaś $8,5 \%$ opracowanych zębów miało akceptowalny kąt zbieżności w płaszczyźnie $\mathrm{MD}$, a tylko $0,85 \% \mathrm{w}$ płaszczyźnie BL.

Redukcja brzegu siecznego/powierzchni okluzyjnej wahała się od 1,8 do 2,2 mm i wynosiła średnio $2 \mathrm{~mm} .{ }^{14} \mathrm{Na}$ podstawie badań El-Mubarak i wsp. ${ }^{5}$ redukcja brzegu siecznego wynosiła średnio $2,3 \mathrm{~mm}$, czyli w porównaniu do idealnej wartości różnica ta była istotna statystycznie. Redukcja powierzchni okluzyjnej dla zębów bocznych wynosiła średnio 2,29 mm dla guzków funkcjonalnych, 1,76 mm dla guzków niefunkcjonalnych i 1,6 mm dla bruzdy centralnej. Redukcja brzegu siecznego/ powierzchni okluzyjnej była wystarczająca w $62,77 \% .{ }^{12}$ Natomiast według innych badań redukcja powierzchni okluzyjnej była odpowiednia w $33,93 \%$ przypadków. ${ }^{7}$

Redukcja osiowa wynosiła dla powierzchni przedsionkowej 1,45 mm, 1,00 mm językowo, 1,42 mm mezjalnie i $1,37 \mathrm{~mm}$ dystalnie. ${ }^{5}$ 
However, according to Tiu et al. ${ }^{10}$ the mean finish line depth was $0.70 \mathrm{~mm}$. Up to $38.46 \%$ of students incorrectly positioned the finish line. $2.56 \%$ of students prepared indistinct finish line and $19.66 \%$ of students did not maintain the continuity. ${ }^{5}$ Research shows that only $41.7 \%$ of students did not touch the adjacent teeth. ${ }^{15}$

Statistical analysis showed the significant difference in convergence angle in the BL and MD plane between the fourth-year dental students and other groups (the fifth-year dental students, clinical teaching staff and general dental practitioners). On the other hand, there are no significant differences between the last three groups. ${ }^{11}$ However, other studies indicate a lack of statistical difference between the teeth prepared by inexperienced postgraduate doctors and specialists. ${ }^{8}$ Moreover, damage to adjacent teeth was observed during preparation. ${ }^{16}$

The research compared the convergence angle depending on the vitality status. For vital teeth, this angle ranged from about $19^{\circ}$ to $27^{\circ}$, while for non-vital teeth values from $12^{\circ}$ to $37^{\circ}$ were obtained. ${ }^{17}$ Higher values were found for non-vital teeth compared to vital teeth. ${ }^{8}$ Studies confirm that there is statistical difference in the convergence angle of the prepared teeth depending on the type of tooth. $5,8,14,18$ The value of the convergence angle was statistically greater for molars compared to other teeth. Research indicates higher values in the mesiodistal plane than in the buccolingual plane. ${ }^{4,13,14}$ In addition, it was claimed that axial wall taper of the buccal surface is greater than for the lingual and proximal surface compared to the distal one. ${ }^{19}$

Pulpal response to preparation is a serious problem in fixed prosthodontics. At least $2 \mathrm{~mm}$ or more of the remaining dentine is critical to pulp protection. However, it is not possible to examine dentine thickness clinically during preparation. Studies on the thickness of dentine after preparing the central upper
Opracowanie ścian osiowych było wystarczające w $54,01 \%$ przypadków. W $12,41 \%$ opracowanych zębach występowały podcienie, a ostre kąty w $21,17 \%{ }^{12}$

Głębokość stopnia typu shoulder według $\mathrm{Al}$ Omari i wsp. ${ }^{14}$ na powierzchni policzkowej wynosiła średnio $0,86 \mathrm{~mm}$, zaś średnia wartość stopnia chamfer na powierzchni językowej $0,74 \mathrm{~mm}$, mezjalnie $0,7 \mathrm{~mm}$, a dystalnie 0,66 $\mathrm{mm}$. Policzkowo stopień shoulder dla przednich zębów żuchwy był znacząco mniejszy niż dla innych zębów i wynosił średnio tylko 0,45 mm. Natomiast według Tiu i wsp. ${ }^{10}$ średnia wartość szerokości stopnia wynosiła $0,70 \mathrm{~mm}$. Aż 38,46\% studentów niepoprawnie umiejscowiło stopień przydziąsłowy. U 2,56\% studentów stopień był niewyraźny, a 19,66\% studentów nie zachowało ciągłości stopnia. ${ }^{5}$ Jak pokazują badania tylko 41,7\% studentów nie dotknęło sąsiednich zębów. ${ }^{15}$

Analiza statystyczna wykazała znaczącą różnicę między studentami czwartego roku a studentami piątego roku, lekarzami dentystami oraz pracownikami dydaktycznymi doświadczonymi w zakresie protetyki zarówno jeśli chodzi o stopień zbieżności w płaszczyźnie BL jak i MD, a także brak znaczącej różnicy między ostatnimi trzema grupami. ${ }^{11}$ Natomiast inne badania wskazują na brak statystycznej różnicy między zębami opracowanymi przez niedoświadczonych lekarzy po studiach a specjalistami. ${ }^{8}$ Natomiast obserwowano uszkodzenie zębów sąsiednich podczas preparacji. ${ }^{16}$

Przeprowadzono badanie, w którym porównano stopień zbieżności w zależności od żywotności zębów. Dla zębów z żywą miazgą kąt ten wynosił od ok. $19^{\circ}$ do $27^{\circ}$, natomiast dla zębów wyleczonych endodontycznie uzyskano wartości od $12^{\circ}$ do $37^{\circ} .{ }^{17}$ Stwierdzono wyższe wartości dla zębów z martwą miazgą w porównaniu do zębów żywych. ${ }^{8}$ Badania potwierdzają, że istnieje statystyczna różnica $\mathrm{w}$ stopniu nachylenia opracowanych zębów w zależności od rodzaju zęba. 5,8,14,18 Wartość kąta zbieżności była 
incisors for a metal-ceramic crown indicate an excessive preparation of the region on the labial surface near the proximal incisal angle. This clinically may affect tooth vitality and restoration. $^{20}$

\section{Summary}

The most common errors in the preparation of retained teeth for permanent restorations are inadequate reduction of cusps and erroneous reduction of the central fissure. No preparation of the functional cusps bevel, which may be lead to occlusal trauma during occlusal articulation is also pointed out. ${ }^{12}$ Frequent errors include incorrect axial reduction and too much convergence of axial walls, which may adversely affect the retention of restorations. Many studies have shown too small depth of the finish line on the vestibular surface. ${ }^{21}$ This creates difficulties in accurate preparation of the crown edge, and disturbs the smooth transition of the restorations to the tooth walls. It leads to dental plaque retention, caries formation and periodontological complications. ${ }^{22}$ The quality of the preparation may be affected by the type of tooth, its vitality, reconstruction status or difficult access. statystycznie większa dla zębów trzonowych w porównaniu do innych zębów. Badania wskazują na wyższe wartości w płaszczyźnie mezjalno-dystalnej niż policzkowo-językowej. $.43,14$ Oprócz tego stwierdzono większe nachylenia ściany policzkowej w porównaniu do językowej oraz bliższej w porównaniu do dalszej. ${ }^{19}$

Reakcja miazgi na szlifowanie jest poważnym problemem podczas wykonywania uzupełnień stałych. Przynajmniej $2 \mathrm{~mm}$ lub więcej pozostałej zębiny ma kluczowe znaczenie dla ochrony miazgi. Jednak klinicznie nie ma możliwości zbadania grubości zębiny w trakcie opracowywania. Badania nad grubością zębiny po oszlifowaniu górnych siekaczy centralnych pod koronę metalowo-ceramiczną wskazują na nadmierne opracowanie regionu na powierzchni wargowej w okolicy bliższego kąta siecznego, co klinicznie może wpłynąć na żywotność zęba i odbudowę. ${ }^{20}$

\section{Podsumowanie}

Najczęściej popełniane błędy w opracowaniu zębów własnych do uzupełnień stałych to nieodpowiednia redukcja guzków oraz niewłaściwa redukcja bruzdy centralnej. Zwraca się także uwagę na brak oszlifowania stoku guzka funkcjonalnego, co może być przyczyną urazu zgryzowego podczas zwarcia dynamicznego. ${ }^{12}$ Często popełniane błędy to nieprawidłowa redukcja osiowa oraz zbyt duża zbieżność ścian osiowych, co może negatywnie wpływać na retencję uzupełnień. W wielu badaniach wykazana została zbyt mała szerokość stopienia na powierzchni przedsionkowej. ${ }^{21}$ Powoduje to trudności w dokładnym wykonaniu brzegu koron i zaburzeniu gładkiego przejścia uzupełnień w ściany zębów. Staje się przyczyną zalegania płytki nazębnej, powstawania próchnicy i powikłań periodontologicznych. ${ }^{22} \mathrm{Na}$ jakość preparacji może wpłynąć rodzaj zęba, jego żywotność, stan odbudowy czy utrudniony dostęp. 


\section{References / Piśmiennictwo}

1. Shillingburg HT, Hobo S, Whitsett LD: Protezy stałe. Zarys postępowania klinicznego i laboratoryjnego, Wydawnictwo Kwintesencja, Warszawa 1994.

2. Dejak B: Kompendium wykonania uzupełnień protetycznych, Wydawnictwo MedTourPress, Otwock 2014.

3. Majewski S: Współczesna protetyka stomatologiczna, Wydawnictwo Elsevier Urban \& Partner, Wrocław 2014, wyd. 1.

4. Tiu J, Cheng E, Hung TC, Yu CC, Lin T, Schwass D, Al-Amleh B: Effectiveness of Crown Preparation Assessment Software As an Educational Tool in Simulation Clinic: A Pilot Study. J Dent Educ 2016; 80(8): 10041011.

5. El-Mubarak N, Abu-Bakr N, Omer O, Ibrahim Y: Assessment of undergraduate students' tooth preparation for full veneer cast restorations. Open J Stomatol 2014; 4: 43-48.

6. Ram HK, Shah RJ, Agrawal HS: Evaluation of three different tooth preparation techniques for metal ceramic crowns by comparing preparation depths: An in vitro study. J Indian Prosthodont Soc 2015; 15: 162-167.

7. Syed S, Al-Moaleem MM, Shariff M: The quality assessment of teeth prepared by fresh graduates for ceramo-metal full coverage crowns. Saudi J Dent Res 2016; 7: 24-28.

8. Ghafoor $R$, Siddiqui AA, Rahman M: Assessment of convergence angle of fullcoverage porcelain fused to metal crowns in clinical practice. Indian J Dent Res 2012; 23(2): 241-246.

9. Rafeek RN, Smith WA, Seymour KG, Zou LF, Samarawickrama DY: Taper of full-veneer crown preparations by dental students at the University of the West Indies, J Prosthodont 2010; 19(7): 580-585.

10. Tiu J, Waddell JN, Al-Amleh B, Jansen van Vuuren WA, Swain MV: Coordinate geometry method for capturing and evaluating crown preparation geometry. J Prosthet Dent 2014; 112(3): 481-487.

11. Patel PB, Wildgoose DG, Winstanley RB: Comparison of convergence angles achieved in posterior teeth prepared for full veneer crowns. Eur J Prosthodont Restor Dent 2005; 13(3): 100-104.

12. Andreescu CF, Banateanu AM, Radulescu $D E$ : Considerations Regarding Preparation for Porcelain-fused-to-metal Crowns. ARC J Dent Sci 2017; 2: 8-10.

13. Rafeek RN, Marchan SM, Seymour KG, Zou $L F$, Samarawickrama DY: Abutment taper of full cast crown preparations by dental students in the UWI School of Dentistry. Eur J Prosthodont Restor Dent 2006; 14: 63-66.

14. Al-Omari WM, Al-Wahadni AM: Convergence angle, occlusal reduction and finish line depth of full-crown preparations made by dental students. Quintessence Int 2004; 35: 287-293.

15. Hey J, Schweyen R, Kupfer P, Beuer F: Influence of preparation design on the quality of tooth preparation in preclinical dental education. J Dent Sci 2017; Issue 1, 12: 27 32.

16. Habib SR: Rubric system for evaluation of crown preparation performed by dental students. Eur J Dent Educ 2018; 22(3): 506513.

17. Ohm E, Silness J: The convergence angle in teeth prepared for artificial crown. J Oral Rehabil 1978; 5: 371-375.

18. Annerstedt A, Engstrom $U$, Hansson A, Jansson $T$, Karlsson $S$, Liljhagen $H$, et al.: Axial wall convergence of full veneer crown preparations. Documented for dental students and general practitioners. Acta Odontologica Scandinavica 1996; 54: 109-112.

19. AL-Moaleem MM, Ahmad M, Porwal A, Elamin EFI, Al Shawkani HA, Quadri MFA: Evaluation of tooth preparation by dental students in Jazan University during pre- 
clinical training. J Oral Health Dent Manag 2014; 13: 1166-1170.

20. Davis GR, Tayeb RA, Seymour KG, Cherukara $G P$ : Quantification of residual dentine thickness following crown preparation. J Dent 2012; 40(7): 571-576.

21. Poon BK, Smales RJ: Assessment of clinical preparations for single gold and ceramometal crowns. Quintessence Int 2001; 32(8): 603610.
22. Seymour KG, Cherukara GP, Samarawickrama $D Y$, et al.: Consistency of labial finish line preparation for metal ceramic crowns: an investigation of a new bur. J Prosthodont 2008; 17: 14-9.

Zaakceptowano do druku: 24.10.2019 r.

Adres autorów: 92-213 Łódź, ul. Pomorska 251.

(C) Zarząd Główny PTS 2019. 